\title{
The Male Order Development Encounter
}

\section{Jerker Edström}

Abstract In order to more helpfully take the men and masculinities field forward within international development, we must reveal deep patriarchal structures of constraint to gender equality. This article frames an approach, by drawing on feminist thinkers, writers on masculinities and thinkers on power, to propose a set of considerations informing how patriarchy might be analysed in depth. Setting out four dimensions (representational, material, ideological and epistemological) in which to undress patriarchy, the article explores male centredness, male privilege, male supremacy and a concept of 'male order'. The latter provides both the deep-level syntax and the inbuilt directionality of patriarchal power structures, through diffuse micro-technologies of gendered knowledge-power. The four dimensions are applied to a characterisation of recent policy discourse on the role of men in gender equality, to then conclude with priorities for research and highlighting the need for making the work more explicitly political as well as personal.

\section{Introduction}

I come to this topic as a white, middle-aged, Northern, heterosexual male with multi-layered structural privileges on most counts. After a symposium on politicising masculinities some six years ago together with a stimulating mixture of international colleagues in Senegal (Esplen and Greig 2008), I felt that the way forward must involve moving beyond the homogenised and individualised framings of development discourse on gender and men. I also felt that those of us engaged with gender and men need to think about masculinities more politically, and in structuralyet-dynamic terms (Edström 2011). If we are to get more politically grounded, I now realise more clearly how many of us need to engage better with feminist thought, as well as with thinking on power and the reality of patriarchy as a resilient and pervasive - if sometimes obscure - 'order' in most societies and structures of power, which also blinkers our own outlooks.

My proposition is that in order to more helpfully take the men and masculinities field forward within international development, we must dig far deeper into the patriarchal structures of constraint to gender equality, in fact into the sub-structural veins and sources of patriarchy itself. We must also: become more self-aware of our positions in all of this; recognise that we are conflicted and limited; and hold ourselves and each other to account in our daily lives and make bigger efforts to build a fairer world, alongside women and others less privileged than ourselves. It is not enough to see men and boys in 'diverse and complex' terms recognising their own vulnerability, etc., although that is indeed an important starting point for any relevant work with different men and boys. More importantly, we must see violence, inequality and oppression as themselves structural and dynamic, with deep old roots in resilient patriarchal orders and in our ways of seeing the world, and ways of interacting within it. This project of undressing patriarchy has been most clearly advanced and described by feminist thinkers thus far, by excavating notions such as the subordination of women, discrimination against women, the marginalisation of women's voices and perspectives, along with all things feminine and, indeed, the notion of deep structures of constraint to gender equality.

In a searching attempt to better follow their lead, I will frame my approach by drawing on a few feminist thinkers, as well as writers on masculinities and on power, in order to propose a set of considerations which could inform how 
patriarchy might be analysed. I will suggest a four-dimensional framework for such an analysis or undressing. I will then go through this

framework, by each proposed dimension, to muse promiscuously on how it may have started to become addressed to greater or lesser degrees in development discourse on the role of men and boys. In a concluding discussion, I finally reflect on the potential implications of this way of analysing patriarchy and on challenges ahead.

\section{Framing the analytic gaze for a disrobing approach}

'Structural approaches' have become more popular recently in debates and policy discussions on gender and development, whether related to issues of health, economic justice or gendered violence. What structural approaches really mean, however, depends partly on what disciplines and sectors you are dealing with, but many approaches in development come back to ecological models of individuals (or households) as nested in proximal-to-distal levels of context, through which 'shocks' are transmitted to these units of analysis, usually framed as 'vulnerable'. On the positive side they encourage us to recognise 'levels' or 'sectors' relevant to the work, as well as to recognise that we are all operating within social systems that need changing. On the more negative side, most structural models often fall back on a small set of composite strategies at different levels or in different sectors aimed at changing individuals (cocooned at the centre of these familiar ecological models). In doing so, they: quickly get abstract, ahistorical, reductive and linear; deal poorly with intersectionality (or, multiple axes of inequity); lend themselves to a sense of determinism; thus constrict unexpected aspects of agency; and, finally, leave the observer (or the benevolent development 'interlocutor') out of the structural dynamic itself.

It is clear that structures and systems shape people, their habits and development. Equally, it is clear that it takes people, in particular constellations and contexts, to create change together (even if facing resistance), including change to reform broader systems. The separation of 'people' from 'the system' is therefore somewhat artificial, but still useful to shift the frame on change beyond the individual level. More than how individual women and men are shaped, or change, a structural approach to gender inequality should focus primarily on how our systems themselves change, and how we can influence such change. For thinking structurally about patriarchy, in particular, I feel it is useful to see it as a 'dynamic system' involving the exercise of powers, resistance and change.

This is not thinking of structure in some monolithic or deterministic way, but seeing patriarchy as evolving historically and being continuously reshaped through adaptations of historical processes and logics of contestation, co-option, domination, resistance, reorganisation and legitimation. This works over time, across generations, through multiple levels and scales of aggregation (from minds and bodies to communities, classes, nations and supra-national formations), as well as across multiple disciplinary domains, or 'sectors' (such as law, medicine, economics, defence, organised religion, art and culture) and, finally, in multiple dimensions. That is, in the case of patriarchy, beyond the relatively visible male-centred cultural dimension of representation to more material institutional male privileges and ideologies of male supremacy down to often virtually invisible epistemological dimensions of meanings in these dynamics and interactions. It is against this outlook on the structural as dynamic system that I want to explore and undress patriarchy, by drawing ideas from other writers, in the following sections, to construct a framework for analysis.

\subsection{Fraser's 'deep structures' of inequity and cooptation in multiple dimensions}

In considering the resilience of capitalism and the mixed fortunes of feminisms' 'dangerous liaisons' with its neoliberal incarnation over the last 40 years or so, Nancy Fraser points out that 'most second-wave feminists - with the notable exception of liberal-feminists - concurred that overcoming women's subordination required radical transformation of the deep structures of the social totality' (Fraser 2009: 104). In referring to second-wave feminist debates about 'how best to characterize... [this] "social totality", Fraser avoids articulations explicitly based on patriarchy and explains her own view that it was at the time 'a historically specific, androcentric form of stateorganized capitalist society, structured by three interpenetrating orders of subordination: (mal)distribution, (mis)recognition and (mis)representation' (ibid.: 104). Moving forward strategically on this consensus was complicated 
by the fact that 'the rise of second-wave feminism coincided with a historical shift in the character of capitalism, from the state-organized variant... to neoliberalist', which essentially 'proposed to use markets to tame politics' (ibid.: 107) rather than vice versa, as was previously the case. This forms part of the basis for her analysis, which very convincingly describes how many current strands of feminism, whilst meeting with several opportunities proffered by neoliberalism, have nevertheless become more or less co-opted under global capitalism.

Whilst I find this very attractive for analysing the 'historical moment' of dual crises in global capitalism and in contemporary feminism, the privileging of logics of capitalism as the main explanation for the 'deep structures' to gender inequities feels slightly unsatisfactory, however. Patriarchal logics of capitalism were clearly built on earlier modalities of 'social totalities' (which may always be 'relative' at any rate), be they agrarian, mercantile, feudal, imperial or city-state slave economies, etc. back in history to some obscure distant point in the past. More useful for my purposes, however, are three particular aspects to her analysis: first, simultaneously looking at gender justice in multiple dimensions (in her case: economic, cultural and political - focusing on 'redistribution', 'recognition' and 'representation'); second, appealing to the 'deep structures' driving this injustice; and, third, exploring the notion of resilient power structures essentially 'co-opting' contesting progressive agendas.

\subsection{Butler on 'gender performativity' and 'phallogocentrism' of the gender-binary}

Another key influence in this, for me, comes from a more queering strand of feminism, namely Judith Butler's (1990) inversion of the sex/gender problem. This helped to clarify the role of relational performativity or habitual and structured practices in the social constructions of gender (rather than sex explaining the patterns of our habits and performances), as also discussed by Karioris in the case of men's 'homosocial' relations (this IDS Bulletin). This has been essential to thinking differently about our relationship to context and breaking away from too binary a view of gender, which sticks together with the more general tendency of reading the world in binaries (or one dimensional scales), as I noted and grappled with in an earlier exploration of 'sticky binaries' whilst looking at masculinities in HIV (Edström 2011). Following Jacques

Derrida, Butler also helpfully combines the two concepts 'phallocentrism' and 'logocentrism' into 'phallogocentrism', to deconstruct a positivistic and dualistic logic to reading the world in binaries, whilst applying it to the problem of that world being mainly identified through a male gaze.

\subsection{Connell and others on 'masculinities' and 'hegemonic masculinity'}

Another strand of important inspiration comes from the field of masculinities research and theory, for its explorations of performed 'masculinities', as multiple/diverse, social, contradictory and contesting, interlinked in hierarchical relationships, as well as dynamic and changing, most influentially presented by Connell (1995). A rich diversity of ethnographic work and publication came out in the late 1980s to mid1990s, charting different masculinities in diverse and comparative settings. As argued forcefully by Andrea Cornwall and Nancy Lindisfarne (1994) such evidence shows how men must be dislocated from any singular notion of masculinity and that particular forms of masculinity can disempower both men and women. Whilst also having encountered various forms of critique, Raewyn Connell and James Messerschmidt's (2005) defence of the concept of 'hegemonic masculinity' feels very helpful to an exploration of patriarchy, especially through its combination of attention to contesting hierarchical power relations amongst men and masculinities, combined with an interesting use of the Gramscian concept of 'hegemony'. The authors point to extensive ethnographic 'evidence of the active struggle for dominance that is implicit in the Gramscian concept of hegemony...' and that, in this evidence, hegemony 'did not mean violence... [primarily]...; it meant ascendancy achieved through culture, institutions, and persuasion' (ibid.: 832). They also point out that 'challenges to hegemony are common, and so are adjustments in the face of these challenges' (ibid.: 835) and that the Gramscian idea of hegemony is one "that embeds certain notions of consent and participation by the subaltern groups' (ibid.: 841). This fits well with the co-option of women's empowerment agendas in individualised and commoditised forms under neoliberalism, observed by Fraser (2009).

Connell and Messerschmidt elaborate on the concept, discussing Demetrakis Demetriou's (2001) distinction between internalised and 
external (more systemic) hegemony and describe how hegemonic masculinity is itself made up of multiple and interlinking masculinities in a dominant 'hegemonic masculine bloc'. This does far more than adapt to changing conditions, but is rather a form of hybridisation actively appropriating diverse or opposing elements, making it 'capable of reconfiguring itself and adapting to the specificities of new historical conjunctures' (Demetriou 2001: 355, cited in Connell and Messerschmidt 2005: 845). This is illustrated by the increasing visibility of gay masculinity in the West, which enables some heterosexual men to appropriate certain inflections of gay culture in hybrid practices, blurring gender differences, yet not necessarily challenging or undermining patriarchy. An extension of this kind of argument could be Patrick Welsh's (this IDS Bulletin) argument about the co-option of some progressive sexual rights leaders' management styles into patriarchal orders. If we then look at women and feminism, also recognising the possibility of women 'performing masculinity', it becomes easier to see how dominant masculinities can appropriate both women's and men's agendas, which may appear very progressive, feminist or pro-feminist without necessarily undermining patriarchy in any deep sense. The exact workings of such patriarchal co-option into new forms of power needs further study, but it is certainly possible that such changes may open up possibilities for gradual shifts.

\subsection{Greig on the 'masculinity of hegemony' in anxious states of power}

In a deeply thoughtful chapter on 'states of anxiety' in contemporary gendered power orders, Alan Greig (2011) explores how shifts in the political economy of gender are causing anxieties amongst those most privileged by existing patriarchal arrangements, at the level of Fraser's (2009) 'deep structural connections'. He argues that gender shifts have the potential to 'destabilize a fundamental tenet of patriarchal ideology, whose masculine/feminine binary serves to naturalize social inequalities... [and]... secure consent to hierarchical social relations' (Greig 2011: 220). Also picking up on the concept of hegemony, Greig appears to reverse 'hegemonic masculinity' and argues that hegemony itself appears very masculine in character and that power and authority are both deeply masculinised, explaining: 'It is this masculinity of hegemony that changes in the gender order threaten to undermine' (ibid.: 220). He then performs a deft analysis - not unlike Fraser (2009) does on the co-option of feminism - and argues that 'the evolution of the "men and masculinities" field, in work on issues of violence and sexual health, must be understood not only in the context of, but also as complicit with, these crisis management efforts of anxious states' (Greig 2011:220) and that, ultimately, 'investing hope in "kinder, gentler expressions of masculinity" as a way to bring about changes in the social order has proved illusory' (ibid.: 233).

\subsection{Other analyses of power as relational, multidimensional and epistemological}

Whilst a fuller treatment of the topic of power, is well beyond my own powers here, I would like to borrow loosely from a few recent thinkers on this old topic. The twentieth century political scientist Robert Dhal famously defined 'power' in rather reductive behaviourist terms, such that 'A has power over B to the extent that he can get $\mathrm{B}$ to do something which B would otherwise not do' (Dahl 1957: 202-3). I find it more useful to follow Lisa VeneKlasen and Valerie Miller (2002), who construct a framing of power by drawing from a range of different thinkers to suggest four different 'kinds' of power, namely: power over (related to Dahl's vision of power relations); power to (focused more on agency and capacity); power with (suggesting power as also social and collective); and, power within (speaking to deeper sources of internalised energy and inspiration). As Robert Chambers discusses in an article on transforming power away from a zero-sum perspective (2006), seeing different kinds of power in this way enables us to see it in more dynamic ways and at different levels. In a project with various colleagues on mobilising men to challenge sexual and genderbased violence in institutional settings (see e.g. Otieno or Das and Singh, this IDS Bulletin) Greig suggested a similar focus on 'levels' to analyse gendered power, arguing that we can see the 'gender-sexuality system, and the violence that comes from it and helps to maintain it, as working at four levels... in the 4I's Framework' (Greig 2012: 46), which encompasses internal (personal), interpersonal, institutional and ideological levels. Whilst also related to the way we internalise gender assumptions, our own roles, identities, etc., the ideological level or 
dimension becomes crucial in patriarchy, for naturalising male supremacy.

In addition to different types of power, or proximal-to-distal levels, other writers point to various other spaces and forms of power for influence and change, such as John Gaventa's (2006) power analysis of open, invited and closed spaces alongside visible, hidden and invisible forms of power. I propose to think about how hidden and invisible powers may operate in terms of patriarchal gender orders, beyond the representational sphere (where a centring on masculinities and male perspectives may 'hide' women's concerns) down to deeper levels of possibilities of visibility at all, rooted in epistemology and constructions of meaning and realities. Michel Foucault's (1978) ideas of knowledge-power as diffuse networks of disciplinary micro-technologies giving rise, visibility and reality to new concepts and constructs, such as the very idea of sexuality, become appealing for these purposes. In terms of a patriarchal dimension to such diffuse systems of knowledge-power, I would also appeal to Butler's focus on 'phallogocentrism' as a particularly gendering form of reductive binary thinking starting with the male.

A final piece of inspiration in this comes from the American sociologist Alan Johnson, who describes patriarchy in analogous terms to a resilient life-form, likened to a tree, with four essential roots into 'deep structures'. He describes these roots as male dominance, male centredness, male identification and an 'obsession with control and order' (Johnson 1997). Whilst not described exactly in these terms by Johnson, I connect his last 'root' with Connell's and Messerschmidt's ideas of the hegemonic bloc (of masculinities) actively struggling to maintain hegemony, as well as with Greig's notion that hegemony itself is masculinised, through a particularly strong and old connection between a reductive binary way of thinking and the supremacy - or 'standard' - of the male as power, automatically 'othering' alternative possibilities. This, I propose to call 'male order', borrowing a term used by a number of writers on masculinities and feminism (e.g. Chapman and Rutherford 1988; Seidler 1994).

So, I propose that an analysis of patriarchy needs to do several things, namely:
- explore the 'deep structures' of gender inequity and cooptation in multiple dimensions, co-evolving historically;

- recognise gender as socially constructed through 'performativity';

- dislocate men from masculinity and women from femininity as a way to understand the vast diversity in lived lives;

- link gendering structures and practices of power to multiple 'masculinities' in constellations of 'hegemonic masculinity';

- explore the masculinity of hegemony itself; and

- see power as relational, dynamic, multidimensional and epistemologically generated, with a reductive 'phallogocentrism' of the gender-binary as central to its more generally reductive logic in its patriarchal form.

\section{Four male dimensions to patriarchy}

It is against this background, then, that I propose an adapted version of Johnson's four roots of patriarchy, by suggesting we explore it in four dimensions (representational, institutional, ideological and epistemological), with clear relevance to key feminist insights about gender injustice. What I call 'the four Ms of patriarchy' should help us to see that:

- 'Male centredness' (in a representational dimension) must be exposed and dislocated to shine a light on the marginalisation of women and subordinate groups' perspectives.

- 'Male privilege' needs to be mapped and rooted out (in an institutional dimension), with its multiple forms of individual and collective discrimination against women and other disadvantaged subjects.

- 'Male supremacy' (in an ideological dimension) must be taken far more seriously, reflectively and honestly in our long, deep and dark - but changing - history of subordination of women, linked to misogyny, racism, nationalism and heterosexism.

- 'Male order' (in an epistemological dimension) must be deciphered, hacked and disrupted, as it provides the deep-level syntax of patriarchal systems of knowledge-power, with their underlying binary-code operating systems, and active obfuscation of potential alternative constructions of sense and meaning as nonsense.

The first three of these dimensions are related to (if somewhat different from) Fraser's three 
dimensions to 'social totality' (as socioeconomic, cultural and political, roughly), which focus on 'redistribution', 'recognition' and 'representation'. They differ slightly from Johnson's roots too. Inevitably they do overlap, or interlink, as dimensions are but alternative and complementary aspects 'of the same reality'. Similarly, they relate to VeneKlasen and Miller's framework of four types of power, as well as Greig's levels of gendered power-systems, but cut slightly differently through the types and levels. Below, I loosely apply each dimension to some developments with masculinities, men and boys in the agendas of gender and development, and, in order to explore the potential of this framing for politicising such work.

\subsection{Male centredness}

We must start by taking seriously feminists' call to reveal and shine a light on the 'male centeredness' of society, with its insidious effect of women's marginalisation. This is both about society's tendency to focus primarily on men and men's interests and the fact that most visible work in the public domain has throughout most of recorded history been done and defined by men, as also described in Marilyn French's (2008) charting of exclusion of women from the prevailing intellectual histories (particularly in Western societies). Of course, feminism as a cultural and intellectual force has itself challenged and begun to reverse this effect from a direction of demanding recognition and visibility.

Within the development field, then, this increased recognition of women and gender inequalities famously received a catalytic spark from Esther Boserup's (1970) pioneering analysis of women's specific roles in processes of economic and social development, incorporating aspects of genderbased divisions of labour in agricultural production and reproduction. Linked to the popularisation of the idea of women in development (WID) and inspiring the first UN Decade on Women (1975-85), these developments increasingly focused on women in a fairly instrumental way, connected to positivistic and economistic theories of modernisation, demographic transition, etc., establishing 'women's roles' as also central to economic development. More recently, feminists such as Cornwall, Harrison and Whitehead (2007) have critiqued the stereotyping effects of such stylised and instrumentalist narratives, as 'myths and fables' about women in development.
However, these have proved highly resilient and remain with us today, in spite of the promise of more contextually rooted analyses proffered in the shift from WID to 'gender and development' (GAD) as being about social and economic relations of power.

It is perhaps slightly ironic then, that the female subject became the overwhelming 'object' of attention in development interventions and policies on gender, whilst women were constructed through an almost imperceptibly 'male gaze' (a fundamentally gender-blind focus on economic, governmental/administrative and technological change). Furthermore, men themselves remained virtually invisible as specifically 'gendered' at all, in this process. In a countervailing trend, however, the emergence of research on masculinities which also connected with broader anthropological research in GAD, resulted in men and masculinities gradually becoming more visible in development from the mid-1990s onward (Cornwall and Lindisfarne 1994; White 1997; Whitehead 2000; Cornwall and White 2000; Cleaver 2002; Chant and Gutmann 2002).

It is within this context that men start to become seen as potential partners in gender work at the international development policy level. The 1994 International Conference on Population and Development (ICPD) challenged men to 'play a full part' in the fight for gender equality (UN 1994); the 1995 Beijing Platform for Action declared that women's concerns could only be addressed 'in partnership with men' (UN 1995); and the 2001 UN General Assembly Special Session on HIV/AIDS addressed men's 'roles and responsibilities' in reducing the spread and impact of HIV (UN 2001). In more programmatic terms, developments in Sexual and Reproductive Health, and HIV in particular, have been instrumental for progress in making men visible in gender (Edström 2011), even if much yet needs to be achieved (Shand et al., this IDS Bulletin), and research like the IMAGES studies has put some clearer contours and visibility to men and women's relations and realities (Barker, this IDS Bulletin). Yet, prevalent discourse on men and boys sometimes risks homogenising men and boys into idealised 'types', trading heavily on core patriarchal values of men's power and responsibility and, thus, treading clumsily on feminist aspirations for women's empowerment and redistribution. 
Another challenge for the men and boys' field here is that it risks inadvertently re-establishing male centredness, and is likely to face resistance from feminist groups and thinkers. To the extent that the argument for male engagement speaks to men's own (often overlooked) vulnerabilities, this easily meets with a charge of setting up false equivalences, which takes us to another dimension.

\subsection{Male privilege}

Recognising and opposing male privilege is fundamentally about the clear feminist call for redistribution and the elimination of multiple forms of discrimination against women, as expressed in - for example - the Convention on the Elimination of all forms of Discrimination Against Women (CEDAW). Yet, what is brought into sharp focus by contextualised research on multiple masculinities is how patriarchy does not benefit all men equally and even harms many men, whilst the structural inequities privileging men over women in general are deeply entrenched institutionally, alongside other forms of discrimination.

In many ways, this area has seen far too little progress in terms of men's engagement and has even become plagued by divisive debates over the drawbacks or benefits of a 'positive discrimination' focusing only on women's economic empowerment, on the one hand, and confounded or obscured by challenges imposed by 'intersectionality', on the other (i.e. class, racial or geopolitical privileges typically override male privilege in the bigger picture). Gender and development has become littered with instrumental, individualised and charitable approaches to bestow 'empowerment' on poor Southern women through women-targeted micro-credit and income generation schemes, whilst the role of poor Southern men has been largely ignored in many contexts (e.g. Hossain and Kelbert, this IDS Bulletin). In one analysis of how the World Bank addresses the role of men in gender inequality, Kate Bedford (2007) explores how it applies a gender-complementary framework to shape nicer masculinities, built on the idea of cooperation to increase men's roles in domestic life in rural Ecuador, thus downstreaming the problem of women's exploitation in the global economy to a more gender-equal sharing of (unpaid) care to the household level.

Recent interest in 'structural drivers' in health and gender is encouraging. However, it has not yet begun to address the role of men, or patriarchal power, in any meaningful way. At local levels at least, the way out must involve a focus on gender-just economic empowerment of communities (transcending women-only or menonly economic approaches). It will also require the men and boys' constituency developing a clearer stance and approach to antidiscrimination and redistribution of wealth (productive assets and entitlements) and political voice, as well as care. At more systemic levels, such struggles and approaches need to connect gender justice with other forms of social and economic justice to forge effective alliances addressing both the state and supra-national structures. Jeff Hearn (2011) points to lessons from Europe, seeing men as both the products of social and economic reforms and as agents of change in reform, which may be instructive for thinking differently about how and why to engage men in structural change and new lessons may also be emerging in places like Brazil. Gary Barker's call (this IDS Bulletin) to literally name and aim for a 50:50 gender-equal sharing of care within future development goals - as both men taking responsibility and as liberating for men may be the first step required for men to move forward in this dimension.

Beyond that (and possibly facilitated by such a move), we must start to treat care and social reproduction as a fully valued part of the economy and sustainable development itself. In working to engage men and boys in development, it becomes crucial to challenge ourselves to see us as being 'part of' the structures we are aiming to change. This also involves ideology, requiring that the personal becomes political and vice versa.

\subsection{Male supremacy}

The ideological dimension, then, reveals and calls into question 'male supremacy' itself and the need for explicitly acknowledging feminists' calls for redress and claims against patriarchy, with its underlying ideology of subordination of women. More than simply about 'male domination' this is about patriarchies' misogynist ideologies of 'supremacy', deeply linked to racial supremacy and heterosexism, subordinating 'others' or sexual minorities, including 'lesser men'. Feminists' understandings of women's subordination are central to appreciating systemic and 'legitimising' aspects to male supremacy, as opposed to a mere issue of 
individual behaviours and attitudes. An international conference on the Continuing Subordination of Women in the Development Process, held at IDS in September 1978, proved a pivotal moment to deepen the analysis of women in development by exploring the framing of women's subordination at a systemic level internationally. This was highly influential in shifting the broader field from WID to the concept of GAD and inspired a string of influential analysis linking gendered supremacy and subordination to international material relations of power and exploitation (e.g. Whitehead 1979; Elson and Pearson 1981; Kabeer 1994).

After well over a decade of feminist and sexual rights mobilisation framed around human rights in the nineties and into the noughties, issues of sexual and gender-based violence (SGBV) and violence against women (VAW) have become increasingly visible and highlighted in international policy and discourse on gender and development. This has gathered particular momentum since the millennium, in a post $9 / 11$ era of increasing 'securitisation' of development discourse. Borrowing sharp rhetorical edges from Andrea Dworkin's (1974) and Susan

Brownmiller's (1975) early radical feminist framings of 'women hating' and a 'war against women', at least two slightly contradictory trends can be seen in these more recent debates. On the one hand, from seeing GBV as a systemic almost monolithic - subordination of women, such rhetoric became deftly co-opted within a neoliberal and individualistic vision of stereotypes. These focus down on interpersonal VAW, or violence against women and girls (VAWG), where solutions get down-streamed to an issue of white Northerners helping to protect poor and vulnerable women of colour in the South from dark and evil Southern men. This is a framing that, not only conveniently downstreams the problem to 'them, over there', but also homogenises gender categories at a local level disconnected from a broader global order, let alone from the conflicted internal dynamic of that encounter.

A second, countervailing trend has focused more deeply on the real complexities of marginalisation and victimisation at the receiving end, often at the margins of societies and at the intersections of social injustices.
Connecting cultures of violence with oppressive or militaristic patriarchal power dynamics - also linking misogyny, racism and heterosexism some began seeing and documenting GBV and SGBV as affecting men as well as women, in very complex ways. Recent international debates in the context of responding to sexual violence in conflict and refugee settings indicate some shifting towards a more inclusive recognition of these connections and the reality of men's vulnerability and victimisation in conflicts - the beginnings of a shift which may be discernible even at international policy levels (Dolan, this IDS Bulletin).

Being a matter of ideology, then, it is perhaps not surprising that the issue of gendered violence quickly becomes political at very personal levels. Whilst men may feel good about taking sides on GBV in solidarity with women, and for using their/our power and influence over other men 'more responsibly', many efforts to mobilise men on this have often shied away from pronouncing a stand on homophobic violence, which is connected. The usual excuse has been a fear of 'turning straight men off' in the process. However, it is also important to recognise that more connections are being made in recent times, maybe more frequently than we may think. But, although we can grapple with our personal prejudices, trying to open our minds to how gendered power works in our own lives, it becomes harder to track the more systemic and global dynamics of ideologies in the development encounter and honestly name our own place within it. So, whilst the rights-based approaches of the nineties colliding with a noughties era of securitising development discourse has opened up some new possibilities for politicising the personal around gendered violence, it is not clear that we are seeing the bigger elephant in the room. That is, for example, the ideological battles of competing patriarchal orders shaping our futures in the new fissures between East and West (including the various strategic applications of organised patriarchal monotheisms and nationalisms re-legitimising competing and/or symbiotic articulations of male supremacy) or new shifts between the older hegemonic blocs centred in the USA and the EU and the diverse rising powers across Brazil, Russia, India, China and South Africa (the BRICS). How can patriarchy keep reinventing itself in these chaotic shifts? 


\subsection{Male order}

Responding to Fraser's (2009) call to excavate, interrogate and undermine the deep structures of constraint to gender equality, which shape and give meanings to our social lives, my final - and most invisible - dimension is the epistemological dimension of 'male order'. Whilst there are clearly many ways to explore the deep structures of evolving 'social totalities' and how these shape patriarchal logics, my suspicion is that patriarchal logics deeply influence the likely (if non-deterministic) pathways of reconfiguration in power orders across local-to-global scales and that they have done so for at least a few millennia.

Admittedly, however, this epistemological look at male-ordered knowledge-power and hegemony is also the most undeveloped and exploratory at this stage. Without recapping the theoretical inspirations for this framing (in Section 2 above), I would argue that male order provides the very syntax of patriarchal systems of knowledge and power in ways that are themselves deeply and peculiarly 'masculine'.

The very core of the logic of patriarchy itself can be extrapolated from the original Greek meaning of the term 'patriarch', as both head of the family and head of the 'race', thus syncretising one vertical logic of an exclusive, linear, masculine descent of power, attribution, legitimacy and meaning, with another one, horizontally delineating the central 'linked group' (or 'kind') and excluding all 'others' (to secure the groups' survival, proliferation, expansion or growth). Ironically, gender analysis may have become too preoccupied with the horizontal axis of kind and others/subalterns, whilst often missing the vertical logic in patriarchies' discriminating swords - or scalpels - slicing down to divide us. After a few millennia of philosophical, scientific, mythological, legal, political, socioeconomic and linguistic evolution (particularly though a Euro-centric sphere, also exported through colonisation, globalisation and 'development') this male order could be tentatively characterised as: discriminating and reductive (excluding of 'complications'), abstract and binary (including gender-binary, thus phallogocentric), homogenising and categorising, focused on control, order, expansion, linear target-driven results, etc.

Being abstract and insisting on a rigid binary logic applied to the world as 'external' and 'objective', male order is also essentially positivistic, taking the observer out of the controlled setting. This, then, depersonalises and depoliticises his/her relationship to the subject(s) under investigation, regulation or control. In most applications, male order is thus perfectly suited to measuring, tracking and ensuring growth, expansion and/or domination, which may be why it has become so hegemonic also in the anxious development encounters of the current securitised neoliberal era. Whilst I do not have the space or capacity to develop these ideas fully here, I would like to draw attention to a few features of contemporary development practice, which are deeply maleordered in the way that I mean.

First, what counts as evidence in donors' recent demand for 'evidence-based approaches' and 'evidence-based policymaking' provides a perfect example in the positivistic tyranny of the Randomised Controlled Trial (RCT), as a 'gold standard' borrowed directly from bio-medical research (normally conducted under controlled laboratory conditions). Whilst the more common practice may in fact be 'policy-based evidence making' (since if researched with sufficient reductivism and excluding controls most policies can be demonstrated), the bigger question in terms of gender dynamics is clearly that these are not really amenable to controlled conditions, methodological individualism or the kind of positivistic view of objective truth in an implied 'external' world.

Related to the above, there is an issue of 'governmentality' in relating to, or managing, Southern developmental subjects in the aid business, who become described and visibilised through categories, labelling and various technological 'approaches' (e.g. HIV prevention peer education for 'MSM') for reaching quantitative targets, with greatest impact at lowest cost. There have been recent critiques of neoliberal, methodological individualism and reductive target-driven approaches in development (Edström and MacGregor 2010; Natsios 2010), as well as some push back from activists, movements and theorists. In a framing paper for a recent Push Forward conference on "Uncovering the Politics of "Evidence" and "Results", held at IDS, Rosalind Eyben (2013) charts the historical trajectory of the 'results agenda' in donor agencies, describing what she 
sees as the 'disciplining effects of artefacts' (ibid.: 8) and she locates the drivers of these approaches (or micro-technologies of knowledgepower) as rooted in 'the need to be seen to be in control' (ibid.: 22), the idea of 'value for money and the politics of accountability' (ibid.: 23), as well as the self-consciously depoliticised, yet public-opinion anxious 'internal dynamics' of the sector. The need to be seen to be in control is characteristic of male order here. The mixing of a focus on value for money with accountability subtly redirects accountability in the development encounter away from accountability to beneficiary towards the donor instead, and, reducing it to 'countability' in the process.

Not only does this deflect attention away from broader injustices in proportional resource flows, as highlighted in Alice Welbourn's (2012) assessment of the state of funding for women living with HIV, but it may also play a role in fragmenting social movements under the weight of competition for meagre resources, along with co-opting progressive agendas with monetary strings attached. Debates about funding for gender justice work with men tend to quickly get bogged down in zero-sum arguments about men appropriating 'women's funding' versus some women's groups framing their claims as rightsbased on ill-founded notions of essentialised vulnerability, which itself underlines the sorry state of how social change for gender equality is even understood. Men's movements, especially at regional and global levels, may need to more vocally and reflectively join critiques of the development industry's male-ordered genderbased labelling (GBL) and box-ticking (in which large parts of both fields are complicit) to ally more effectively with women's and sexual rights movements to jointly advocate for raising the bar for resourcing work on gender justice and human rights more broadly. If this proposal appears naively optimistic, that possibility underlines the formidable power of male order to divide and rule.

Yet another aspect to how male order in development obscures the broader architectures of patriarchy is the obfuscation of the problem of intersectionality (between gender, class, race or sexuality). This problem gets conveniently 'solved' by the reductive logic of simplification, exclusion and 'controlling for confounding factors'. The concomitant simplifying assumptions of 'all things being equal' may thus also undermine the possibilities for forging alliances across social justice movements at a deep level of invisibilising knowledge-power. Of course, things never are equal and many women and men have shared grievances, but these become obscured and divided along the deep programmatic canyons of the arid aid landscape.

\section{Concluding discussion}

To sum up then, three dimensions of - roughly representation, materiality and ideology provide a statuesque shape or space to patriarchy, which demands considerable effort to be perceived at all, especially by us men. First, we must expose male centredness, by dislocating masculinity from men and shining a light on the many ways masculinities and patriarchy marginalises as well as co-opts women, subordinate groups (of any gender) and many men. Second, the multiple forms of individual and collective discrimination against women and others who are disadvantaged needs to be better mapped out, in order to begin to figure out how male privilege can be abolished and rendered obsolete. Third, we must personally reflect seriously and honestly to come to terms with male supremacy in our lives and our collective history of subordination of women, misogyny, racism and homophobia, which damages and cheapens us all. Yet, a three-dimensional shape to patriarchy looks 'dead', however elaborate and formidable the robes. So, we need to explain how patriarchy clings on, adapts and evolves through time and against opposition, as it clearly has done for millennia. A fourth dimension, then, gives it motion, direction, a logic and 'power' - i.e. life. This dimension is male order and it must be hacked into, deciphered and disrupted, as it appears to provide both the deeplevel syntax (a phallogocentric, binary operating code) and the inbuilt directionality of patriarchal orders (aiming at expansion and control), with their networks of diffuse micro-technologies of gendered knowledge-power.

So is this vision and framework overly negative? I think not, as it is not totalising, deterministic, or absolute in any sense. Different patriarchal orders interlink, coexist and compete; most are frequently contested from within (and/or from without), actively striving to co-opt, as well as to co-evolve whilst struggling for hegemony. Furthermore, different systems of power are patriarchal to different degrees: it is important to remember that many societies have become considerably less so, importantly, in part as a result 
of feminism over the last century or so, but also aided by more external trends and events such as shifts in labour-market participation during and after two World Wars and a range of other factors, more or less 'accidental'. However, we have also seen resurgent patriarchal trends lately, so optimistic complacency is ill advised in the present. Whether patriarchal logics are ultimately a good basis for sustainable development is a key question for the sector, as they not only favour 'growth' but also oppression and conflict.

But how is this different from racist or classist oppressive systems? And why not pursue the notion of kyriarchy instead, as flagged by Frank Karioris (this IDS Bulletin), which suggests multiple systems of oppression interacting without the necessity of one being more fundamental that others? I believe this serves to dilute a focus on the pervasive and resilient reality of patriarchy and it also seems to suggest a misunderstanding of what patriarchy really is. It may obscure the essential role of 'gendering' in relational power dynamics and contestations of most kinds. I would argue that patriarchy, in a very tangible sense, provides the 'blueprint' for most other known forms of oppression, which become expressed or imbricated through patriarchal logics, even if surface-level articulations appear distinct. I think we can speak meaningfully about the 'masculinity of hegemony' in a way that would make far less sense for any 'whiteness of hegemony' (which, though epochally coincidental, is far more limited to European colonialism and some of its current globalised follow-on projects). Patriarchy is a more powerful organising principle because it can account for racism, elitism and homophobia, whereas the opposite is not plausible in the cold light of world history and male order.

I would suggest that a more productive direction for exploring the intersectional aspects to

\section{References}

Bedford, K. (2007) 'The Imperative of Male Inclusion: How Institutional Context Influences World Bank Gender Policy', International Feminist Journal of Politics 9.3: 289-311

Boserup, E. (1970) Woman's Role in Economic Development, London: Earthscan

Brownmiller, S. (1975) Against Our Will: Men, Women and Rape, New York: Simon \& Schuster patriarchy and gender injustice needs to combine with good and focused feminist analysis, for example, on how different patriarchal power structures are operating and are male ordered in mutually supportive - and/or competing - ways, across sectors or spheres. Collaborative research on 'men in power' comes to mind, as shorthand for: exploring the ways in which male centredness, privilege, supremacy and order might operate across the upper echelons of security, health, financial, religious, legal, governmental and development sectors. This might involve exploring how 'old boys networks', disciplinary knowledge systems, policies, practices and incentives, or ideologies and cultures interlink across these sectors. Such research could both help to undress its workings better, as well as to identify opportunities and strategies for reform and alternative pathways, if carried out in conversation with contesting 'subalterns'.

For those of us engaged in this field of exploring masculinities in development and in engaging men and boys in gender equality work, what may be needed more than anything is to really start making the work more explicitly political as well as personal. And, that will mean not just personally 'doing the right thing' in some selfseeking kind of way, but actually getting more personal and reflective about our own various privileges; particularly as men (of any race, class or sexuality, etc.), but also as whites (including LGBTI, working class, etc.), as able-bodied or as upper/middle class and so on. We are all turning the wheels of patriarchy together, but to different degrees. For those of us benefiting from multiple advantages, the effort must be even greater. Even if - for whatever different reasons - some cannot declare themselves feminists, I believe that to work credibly with men and boys for gender equality you cannot sit on the fence but must elaborate and take a personal and political stand on patriarchy.

Butler, J. (1990) Gender Trouble: Feminism and the Subversion of Identity, New York and London: Routledge

Chambers, R. (2006) 'Transforming Power: From Zero-Sum to Win-Win?', IDS Bulletin 37.6: 33-40

Chant, S. and Gutmann, M. (2002) "'Menstreaming" Gender? Questions for Gender and Development Policy in the 21st Century', Progress in Development Studies 2.4: 269-82 
Chapman, R. and Rutherford, J. (1988) Male Order: Unwrapping Masculinity, London: Lawrence \& Wishart Ltd

Cleaver, F. (ed.) (2002) Masculinities Matter! Men, Gender and Development, London and New York: Zed Books

Connell, R.W. (1995) Masculinities, Cambridge: Polity Press

Connell, R.W. and Messerschmidt, J. (2005) 'Hegemonic Masculinity: Rethinking the Concept', Gender and Society 19.6: 829-59

Cornwall, A. and Lindisfarne, N. (1994) Dislocating Masculinity: Comparative Ethnographies, London and New York: Routledge

Cornwall, A. and White, S. (2000) 'Men, Masculinities and Development: Politics, Policies and Practices', IDS Bulletin 31.2: 1-6

Cornwall, A.; Harrison, E. and Whitehead, A. (2007) 'Gender Myths and Feminist Fables: The Struggle for Interpretive Power in Gender and Development', Development and Change 38.1: 1-20

Dahl, R.A. (1957) 'The Concept of Power', Behavioral Science 2.3: 201-15

Demetriou, D.Z. (2001) 'Connell's Concept of Hegemonic Masculinity: A Critique', Theory and Society 30.3: 337-61

Dworkin, A. (1974) Woman Hating: A Radical Look at Sexuality, New York: Penguin Group USA Inc.

Edström, J. (2011) 'Masculinity and HIV: Di-visions of Bodies, Sex and Structural Context', in A. Cornwall, J. Edström and A. Greig, Men and Development: Politicizing Masculinities, London: Zed Books: 71-82

Edström, J. and MacGregor, H. (2010) 'The Pipers Call their Tunes in Global Aid for AIDS: The Global Financial Architecture for HIV Funding as Seen by Local Stakeholders in Kenya, Malawi and Zambia', Global Health Governance Journal, Fall

Elson, D. and Pearson, R. (1981) 'Nimble Fingers make Cheap Workers': An Analysis of Women's Employment in Third World Export Manufacturing', Feminist Review 7: 87-107

Esplen, E. and Greig, A. with A. Cornwall and J. Edström (2008) Politicising Masculinities: Beyond the Personal, Report of an International Symposium held in Dakar, October 2007, Brighton: IDS

Eyben, R. (2013) 'Uncovering the Politics of "Evidence" and "Results": A Framing Paper for Development Practitioners', Brighton: IDS, www.ids.ac.uk/publication/uncoveringthe-politics-of-evidence-and-results-a-framing- paper-for-development-practitioners (accessed 20 November 2013)

Foucault, M. (1978) History of Sexuality, Vol I, New York: Vintage Books

Fraser, N. (2009) 'Feminism, Capitalism and the Cunning of History', New Left Review 56: 97-117

French, M. (2008) From Eve to Dawn: A History of Women, New York: Feminist Press at the City University of New York

Gaventa, J. (2006) 'Finding the Spaces for Change: A Power Analysis', IDS Bulletin 37.6: 23-33

Greig, A. (2011) 'Anxious States and Directions for Masculinities Work with Men', in A. Cornwall, J. Edström and A. Greig (eds), Men and Development: Politicizing Masculinities, London: Zed Books: 219-35

Greig, A. with Edström, J. (2012) Mobilising Men in Practice: Challenging Sexual and Gender-based Violence in Institutional Settings, Brighton: IDS

Hearn, J. (2011) 'Gender Regimes Changing Men or Men Changing Gender Regimes? Challenges for National and Transnational Social Policy, Gender Equality and Organizing with Men', in A. Cornwall, J. Edström and A. Greig (eds), Men and Development: Politicizing Masculinities, London: Zed Books: 155-69

Johnson, A.G. (1997) The Gender Knot: Unravelling Our Patriarchal Legacy, Philadelphia: Temple University Press

Kabeer, N. (1994) Reversed Realities: Gender Hierarchies in Development Thought, London and New York: Verso

Natsios, A. (2010) The Clash of the CounterBureaucracy and Development, Center for Global Development Essay, Washington DC: Center for Global Development, www.cgdev.org/content/ publications/detail/1424271 (accessed 20 November 2013)

Seidler, V.J. (1994) Unreasonable Men: Masculinity and Social Theory (Male Orders), London and New York: Routledge

UN (2001) Declaration of Commitment on HIV/AIDS at the United Nations, 27 June 2001, United Nations General Assembly Twenty-Sixth Special Session, Doc: A/s-26/L.2, www.un.org/ga/aids/ docs/aress262.pdf (accessed 20 November 2013)

UN (1995) 'Beijing Declaration and Platform for Action', Fourth World Conference on Women, www.un.org/womenwatch/daw/beijing/pdf/ BDPfA\%20E.pdf (accessed 20 November 2013)

UN (1994) Report of the International Conference on Population and Development, Cairo, 5-13 
September, www.un.org/popin/icpd/conference/ offeng/poa.html (accessed 20 November 2013)

VeneKlasen, L. and Miller, V. (2002) A New Weave of Power, People and Politics: The Action Guide for Advocacy and Citizen Participation, Oklahoma City: World Neighbors

Welbourn, A. (2012) 'The Gender Politics of Funding Women Human Rights Defenders, 50:50 Inclusive Democracy', Open Democracy, www.opendemocracy.net/5050/alice-welbourn/ gender-politics-of-funding-women-humanrights-defenders (accessed 20 November 2013)

White, S. (1997) 'Men, Masculinities, and Politics of Development', Gender and Development 5.2:

$14-22$
Whitehead, A. (2000) 'Continuities and

Discontinuities in Political Constructions of the Working Man in Rural Sub-Saharan Africa: The "Lazy Man" in African Agriculture', European Journal of Development Research 12: 23-52 Whitehead, A. (1979) 'Some Preliminary Notes on the Subordination of Women', IDS Bulletin 10.3, Special Issue on the Continuing Subordination of Women in the Development Process, Brighton: IDS 